
Krzysztof CENDROWSKI2

\title{
THE EFFECTS NANO-SILVER ON CONTAMINATION OF SPRING BARLEY 'EUNOVA' IN VITRO
}

\section{WPŁYW NANOSREBRA NA ZAKAŻENIA W KULTURACH IN VITRO JĘCZMIENIA JAREGO 'EUNOVA'}

Department of Plant Genetics, Breeding and Biotechnology, West Pomerania University of Technology, Szczecin, Poland

1Department of Horticulture, West Pomerania University of Technology, Szczecin, Poland ${ }^{2}$ Nanomaterials Physicochemistry Department, West Pomeranian University

of Technology, Szczecin, Poland

\begin{abstract}
Streszczenie. Jedną z nowych metod dezynfekcji materiału roślinnego w kulturach in vitro jest zastosowanie noanosrebra. Związek ten nie wykazuje toksycznego działania na roślinę, natomiast cechuje się wysoką skutecznością w eliminowaniu zakażeń bakteryjnych, wirusowych czy grzybowych. W pracy zbadano wpływ różnych stężeń i sposobów aplikacji nanosrebra na skuteczność dezynfekcji, cechy morfologiczne (wysokość i długość korzeni) oraz barwę liści jęczmienia jarego 'Eunova' w kulturach in vitro. Materiałem wyjściowym doświadczenia były zarodki jęczmienia, które wykładano na pożywkę MS uzupełnioną $4.0 \mathrm{i} 6.0 \mathrm{mg} \cdot \mathrm{dm}^{-3}$ nanosrebra oraz zarodki moczone wcześniej w roztworze nanosrebra 50 i $100 \mathrm{mg} \cdot \mathrm{dm}^{-3}$ w czasie 2 i $4 \mathrm{~h}$. Zarodki jęczmienia moczone 70-procentowym alkoholem etylowym stanowiły próbę kontrolną. Po 28 dniach doświadczenia zaobserwowano, że zarówno sposób dezynfekcji, jak i czas działania oraz stężenie roztworu nanosrebra miały wpływ na liczbę zakażeń, długość pędu i korzeni oraz barwę liści siewek jęczmienia. Najmniej skuteczne (100\% zakażeń) okazało się moczenie zarodków w $50 \mathrm{mg} \cdot \mathrm{dm}^{-3}$ roztworu nanosrebra przez 2 h. Natomiast najlepszą skuteczność dezynfekcji (brak zakażeń) uzyskano po dodaniu do pożywki MS $4.0 \mathrm{mg} \cdot \mathrm{dm}^{-3}$ nanosrebra. Podobną skuteczność dezynfekcji uzyskano, mocząc zarodki w $100 \mathrm{mg} \cdot \mathrm{dm}^{-3}$ roztworu nanosrebra oraz wykładając zarodki na pożywkę MS uzupełnioną nanosrebrem, niezależnie od jego stężenia.
\end{abstract}

Key words: contamination, Hordeum vulgare, silver nanoparticle, tissue culture.

Słowa kluczowe: cząsteczki nanosrebra, Hordeum vulgare, kultury tkankowe, zakażenia.

\section{INTRODUCTION}

In vitro cultures is one of the methods used for the rapid multiplication of many plant species, regardless of weather conditions (Osman et al. 2013; Tarinejad 2013; Krupa-Małkiewicz and Ochmian 2014; Teixeira da Silva et al. 2016). However, the success of micropropagation is determined by many factors. One of them is the effective removal of exogenous and endogenous microorganisms (Shokri et al. 2014). The most common pathogens infecting plant

Corresponding author - Adres do korespondencji: Marcelina Krupa-Małkiewicz, Department of Plant Genetics, Breeding and Biotechnology, West Pomerania University of Technology, Szczecin, Juliusza Słowackiego 17, 71-434 Szczecin, Poland, e-mail: mkrupa@zut.edu.pl 
cultures are bacteria, fungi and even yeast (Abdi et al. 2008). There are many methods available to eliminate infections during plant propagation. However, the effectiveness of these methods is insufficient and some are even toxic to the plants themselves (Rostami and Shahsavar 2009). Often, antibiotics are used to remove bacteria from the surface of the material (Abdi et al. 2008). However, they may be toxic to the plant and inhibit their growth. Too long antibiotic action on cells or plant tissues can also cause changes at the genetic level - mutations (Abdi et al 2008). Other commonly used disinfectants explants are chemical compounds: $70 \%$ ethanol, mercuric chloride $\left(\mathrm{HgCl}_{2}\right)$, sodium hypochlorite $(\mathrm{NaOCl})$ or calcium hypochlorite $\left(\mathrm{CaOCl}_{2}\right)$. However, these compounds should be used in appropriately selected doses and exposure times. Otherwise, they may have a toxic effect on the plant. They are also toxic to the environment (Rostami and Shahsavar 2009). In the literature, there are many reports concerning the selection of effective methods of disinfection (Teixeira et al. 2006; Tiwari et al. 2012; Amiri et al. 2013; Zeng 2014; Teixeira da Silva et al. 2016). All of these studies were aimed at establishing a balance between a high decontamination efficiency of explants while maintaining their high survival and ability to regenerate.

Nano-silver is a non-toxic molecule of size less than $100 \mathrm{~nm}$, characterized by high efficiency in eliminating bacterial infections (Abdi et al. 2008; Rostami and Shahsavar 2009; Sarmast et al. 2011; Shokri et al. 2014). Silver ions interact with many processes at the molecular level in bacterial cells, resulting in the inhibition of their growth and even death (Abdi et al. 2008). The use of $\mathrm{AgNO}_{3}$ as a source of silver for disinfection of plant tissues is quite common (Microbial contamination... 1996). While the use of nano-silver is a method used recently. In studies Abdi et al. (2008) shown that nano-silver has similar effectiveness as $\mathrm{AgNO}_{3}$. Inhibiting the development of more than 600 different microorganisms. While Nomiya et al. (2004) and Sondi and Salopek-Sondi (2004) have shown that nano-silver is not only characterized by antibacterial but also antiviral and antifungal effects. In addition, the appropriately selected nano-silver concentration has no negative effect on the growth and multiplication of plants in in vitro culture.

The purpose of the study was to determine the impact of different concentrations and the way nano-silver application on the effectiveness of disinfection and morphological features of spring barley 'Eunova' in in vitro cultures.

\section{MATERIAL AND METHODS}

The study material consisted undressed seeds of spring barley (Hordeum vulgare var. 'Eunova').

Disinfection by sulphuric acid and sodium hypochlorite. Seeds were submerged in $0.5 \% \mathrm{H}_{2} \mathrm{SO}_{4}$ solution for 20 minutes and after three times rinsing in sterile distilled water, they were submerged in $7 \% \mathrm{NaOCl}$ for 10 minutes. After sodium hypochlorite treatment, seeds were washed thoroughly for tree times in sterile distilled water, and next soaked in water for 24 hours. Then embryos were excised with a needle, kept in $2 \%$ sodium hypochlorite for 10 minutes, rinsed with sterile distilled water. For each combination of the experiment, 200 embryos were used. 
Disinfection treatments by nano-silver. Nano-silver treatments included: (1) immersion of explants in nano-silver solutions; (2) adding nano-silver to media.

1) embryos were immersed in 0,50 and $100 \mathrm{mg} \cdot \mathrm{dm}^{-3}$ nano-silver solutions prepared in sterile distilled water;

2) different amount of nano-silver $\left(0,4.0\right.$ and $\left.6.0 \mathrm{mg} \cdot \mathrm{dm}^{-3}\right)$ were added to the media as disinfection agent and then media were autoclaved.

Medium and culture condition. Embryos were placed in the Eppendorf tube with $15 \mathrm{ml}$ of MS medium (Murashige and Skoog 1962). The medium was supplemented with $30 \mathrm{~g} \cdot \mathrm{dm}^{-3}$ of sucrose, $8 \mathrm{~g} \cdot \mathrm{dm}^{-3}$ of agar and $100 \mathrm{mg} \cdot \mathrm{dm}^{-3}$ myo-inositol. The $\mathrm{pH}$ of medium adjusted to 5.7 with $\mathrm{HCl}$ or $\mathrm{NaOH}$ and then autoclaved at $121^{\circ} \mathrm{C}$ for 19 minutes. All cultures were incubated in a culture room at a temperature of $24 \pm^{\circ} \mathrm{C}$ under 16 hours photoperiod with a photosynthetic photon flux density (PPFD) of $40 \mu \mathrm{mol} \cdot \mathrm{m}^{-2} \cdot \mathrm{s}^{-1}$.

Contamination and germination rate, shoots and roots length and leaf pigmentation were analyzed after 28 days for each combination. The leaf pigmentation measurement was carried out using spectrophotometer CM-700d (Konica Minolta, Japan), consisting of a head with an $3 \mathrm{~mm}$ diameter measuring area. Measurements were made in CIE L*a*b* system, in which $L^{*}$ stands for white $(100)$ and black colour $(0)$, $a^{*}$ - green $(-100)$ and red colour $(+100)$, $b^{*}-$ blue $(-100)$ and yellow colour $(+100)$ (Hunterlab 2012). The $10^{\circ}$ observer type and D65 illuminant were applied. Colour was measured in triplicates for each experimental combination.

Statistical analysis. The experiment design was a Complete Randomized Design (CRD) with four replications and 50 Eppendorf tubes per replication and one embryo per tube. The significance of differences was determined by means of variance analysis and Tukey's test, at level of significance of $\alpha=0.05$. Homogenous groups between analyzed combinations were labeled with successive letters of the alphabet.

\section{RESULT AND DISCUSSION}

Generally, nano-silver either submerging or adding into MS medium have an influence on germinating rate of barley embryos in in vitro culture (Table 1). The lowest disinfection efficiencies were observed after soaking of barley embryos in $50 \mathrm{mg} \cdot \mathrm{dm}^{-3}$ nano-silver solution for 2 hours. It was observed $100 \%$ of infected barley embryos. In contrast, no infection was observed among embryos on MS medium supplemented with $4.0 \mathrm{mg} \cdot \mathrm{dm}^{-3}$ of nano-silver. However, the percentage of germinated barley embryos was low $(30 \%)$. The similar efficiency of disinfection rate (80\%) was observed after submerged of barley embryos in $100 \mathrm{mg} \cdot \mathrm{dm}^{-3}$ of nano-silver solution for 2 hours. In this combination, the germination rate was $60 \%$.

Abdi et al. (2008) for disinfection of Valeriana officinalis L. explants used nano-silver solution in three concentrations $\left(25,50\right.$ and $\left.100 \mathrm{mg} \cdot \mathrm{dm}^{-3}\right)$ submerging shoots for 30,60 and 180 minutes. They observed that the submerging explants in the higher concentration of the nanosilver solution (100 $\mathrm{mg} \cdot \mathrm{dm}^{-3}$ ) for a longer period of time (180 minutes) caused higher mold fungal reducibility. Similarly, Sarmast et al. (2011) for disinfection of shoots explants of Araucaria excela R. BR. var. glaca applied nano-silver solution in three concentrations 100 , 200 and $400 \mathrm{mg} \cdot \mathrm{dm}^{-3}$ for 60 or 180 minutes. They have also confirmed that shoots submerging in higher concentration $\left(400 \mathrm{mg} \cdot \mathrm{dm}^{-3}\right)$ of nano-silver solution for the longest time 
(180 minutes) reduced the number of bacterial and fungal contaminations by $32.16 \%$. While addition to the MS medium $400 \mathrm{mg} \cdot \mathrm{dm}^{-3}$ of nano-silver decreased the number of bacterial contaminations from $81.25 \%$ to $18.75 \%$. Shokri et al. (2014) showed, that adds to the MS medium $100 \mathrm{ppm}$ of nano-silver decreased the number of bacterial contamination from $70 \%$ to $17.5 \%$, and $87.5 \%$ rose (Rosa hybryda L.) explants were able to developed shoots. In addition, submerging of rose explants in 200 ppm of nano-silver solution for 20 minutes showed the best disinfection efficiency. According to Shokri et al. (2014) adding nano-silver to the MS medium allowed to obtain the highest efficiency of disinfection with the higher explants regeneration rate with a comparison to the submerging method.

Table 1. Influence of concentration and application method of nano-silver on sterility of in vitro cultures of spring barley 'Eunova'

Tabela 1. Wpływ stężenia i sposobu aplikacji nanosrebra na sterylność kultur in vitro jęczmienia jarego 'Eunova'

\begin{tabular}{lccc}
\hline $\begin{array}{c}\text { Disinfection method } \\
\text { Sposób dezynfekcji }\end{array}$ & $\begin{array}{c}\text { Percentage of contaminated } \\
\text { embryos } \\
\text { Procent zakażonych zarodków }\end{array}$ & $\begin{array}{c}\text { Percentage of uncontaminated embryos } \\
\text { Procent niezakażonych zarodków }\end{array}$ \\
\cline { 3 - 4 } & $\begin{array}{c}\text { germinated } \\
\text { skiełkowanych }\end{array}$ & $\begin{array}{c}\text { no germinated } \\
\text { nieskiełkowanych }\end{array}$ \\
\hline Control - Kontrola & Added to MS medium - Dodatek to pożywki MS & 20.0 \\
\hline $\mathrm{MS}+4 \mathrm{mg} \cdot \mathrm{dm}^{-3} \mathrm{Ag}$ & 0.0 & 30.0 & 70.0 \\
\hline $\mathrm{MS}+6 \mathrm{mg} \cdot \mathrm{dm}^{-3} \mathrm{Ag}$ & 30.0 & 27.5 & 42.5 \\
\hline & Embryos immersion - Moczenie zarodków & 0.0 \\
\hline $50 \mathrm{mg} \cdot \mathrm{dm}^{-3} 2 \mathrm{~h}$ & 100.0 & 0.0 & 42.5 \\
\hline $50 \mathrm{mg} \cdot \mathrm{dm}^{-3} 4 \mathrm{~h}$ & 37.5 & 20.0 & 20.0 \\
\hline $100 \mathrm{mg} \cdot \mathrm{dm}^{-3} 2 \mathrm{~h}$ & 20.0 & 60.0 & 50.0 \\
\hline $100 \mathrm{mg} \cdot \mathrm{dm}^{-3} 4 \mathrm{~h}$ & 25.0 & 25.0 & \\
\hline
\end{tabular}

In the present study, we demonstrated the influence of nano-silver on the morphological traits of spring barley (Table 2). Addition of nano-silver to the MS medium stimulated the shoots and roots length of barley seedlings (Fig. 1a). On the other hand, soaking of barley embryos in $100 \mathrm{mg} \cdot \mathrm{dm}^{-3}$ of nano-silver solution for 2 hours resulted in nearly three times longer length of barley shoots ( $186 \%$ of control) and over twice the root length ( $137 \%$ of control) compared to the control (Fig. 1b). However, submerging of barley embryos in $100 \mathrm{mg} \cdot \mathrm{dm}^{-3}$ of nano-silver for 4 hours showed inhibitory effects on shoots and roots length. Barley seedling from this combination of the experiment were lower than control by $41.6 \%$ and $47.7 \%$, respectively (Table 2). The influence of nano-silver on the morphological traits of plants was described by Rostami and Shahsavar (2009). They showed, that higher concentration of nano-silver $\left(6.0 \mathrm{mg} \cdot \mathrm{dm}^{-3}\right)$ in MS medium decrease Olea europaea L. plant growth. According to Sarmast et al. (2011), addition to MS medium over $800 \mathrm{mg} \cdot \mathrm{dm}^{-3}$ of nano-silver caused browning and necrosis of the $A$. excelsa plants.

No study investigating the effects of nano-silver on contents of leaf dyes. Present results showed that addition 4.0 or $6.0 \mathrm{mg} \cdot \mathrm{dm}^{-3}$ of nano-silver to MS medium or submerging of embryos in $100 \mathrm{mg} \cdot \mathrm{dm}^{-3}$ in nano-silver solution seemed to reduce the colour of the barley seedlings, compared with the control (Fig. 2). It was evidenced by parameter $L^{*}$, which was higher by $50 \%$ compared with control. Parameter $L^{*}$ is related to the physiological attributes of visual response (Wrolstad et al. 2005). 
Table 2. Influence of concentration and application method of nano-silver on plant high and root length of spring barley 'Eunova'

Tabela 2. Wpływ stężenia i sposobu aplikacji nanosrebra na wysokość roślin i długość korzeni siewek jęczmienia jarego 'Eunova'

\begin{tabular}{|c|c|c|c|c|}
\hline $\begin{array}{c}\text { Noano-silver application } \\
\text { Aplikacja nanosrebra }\end{array}$ & \multicolumn{2}{|c|}{$\begin{array}{c}\text { Plant height } \\
\text { Wysokość roślin [cm] }\end{array}$} & \multicolumn{2}{|c|}{$\begin{array}{c}\text { Root length } \\
\text { Długość korzeni [cm] }\end{array}$} \\
\hline Control - Kontrola & 1.97 & $a b$ & 0.62 & $a b$ \\
\hline \multicolumn{5}{|c|}{ Added to MS medium - Dodatek to pożywki MS } \\
\hline $\mathrm{MS}+4 \mathrm{mg} \cdot \mathrm{dm}^{-3} \mathrm{Ag}$ & 3.80 & $a b$ & 1.22 & $a b$ \\
\hline $\mathrm{MS}+6 \mathrm{mg} \cdot \mathrm{dm}^{-3} \mathrm{Ag}$ & 3.95 & $a b$ & 1.94 & a \\
\hline \multicolumn{5}{|c|}{ Embryos immersion - Moczenie zarodków } \\
\hline $50 \mathrm{mg} \cdot \mathrm{dm}^{-3} 2 \mathrm{~h}$ & - & $\mathrm{b}$ & - & $\mathrm{b}$ \\
\hline $100 \mathrm{mg} \cdot \mathrm{dm}^{-3} 2 \mathrm{~h}$ & 5.64 & $\mathrm{a}$ & 1.47 & $a b$ \\
\hline $50 \mathrm{mg} \cdot \mathrm{dm}^{-3} 4 \mathrm{~h}$ & 1.15 & $\mathrm{~b}$ & 0.60 & $a b$ \\
\hline $100 \mathrm{mg} \cdot \mathrm{dm}^{-3} 4 \mathrm{~h}$ & 1.03 & $\mathrm{~b}$ & 0.23 & $a b$ \\
\hline $\operatorname{LSD}_{\alpha=0.05}-\mathrm{NIR} \mathrm{R}_{\alpha=0,05}$ & 4.36 & & 1.86 & \\
\hline
\end{tabular}

Means in the same column followed by the same letter are not significantly different $(\alpha<0.05$; Least Significant Differences test LSD) - Średnie oznaczone tymi samymi literami alfabetu nie różnią się istotnie $(\alpha<0,05$; NIR najmniejsza istotna różnica).
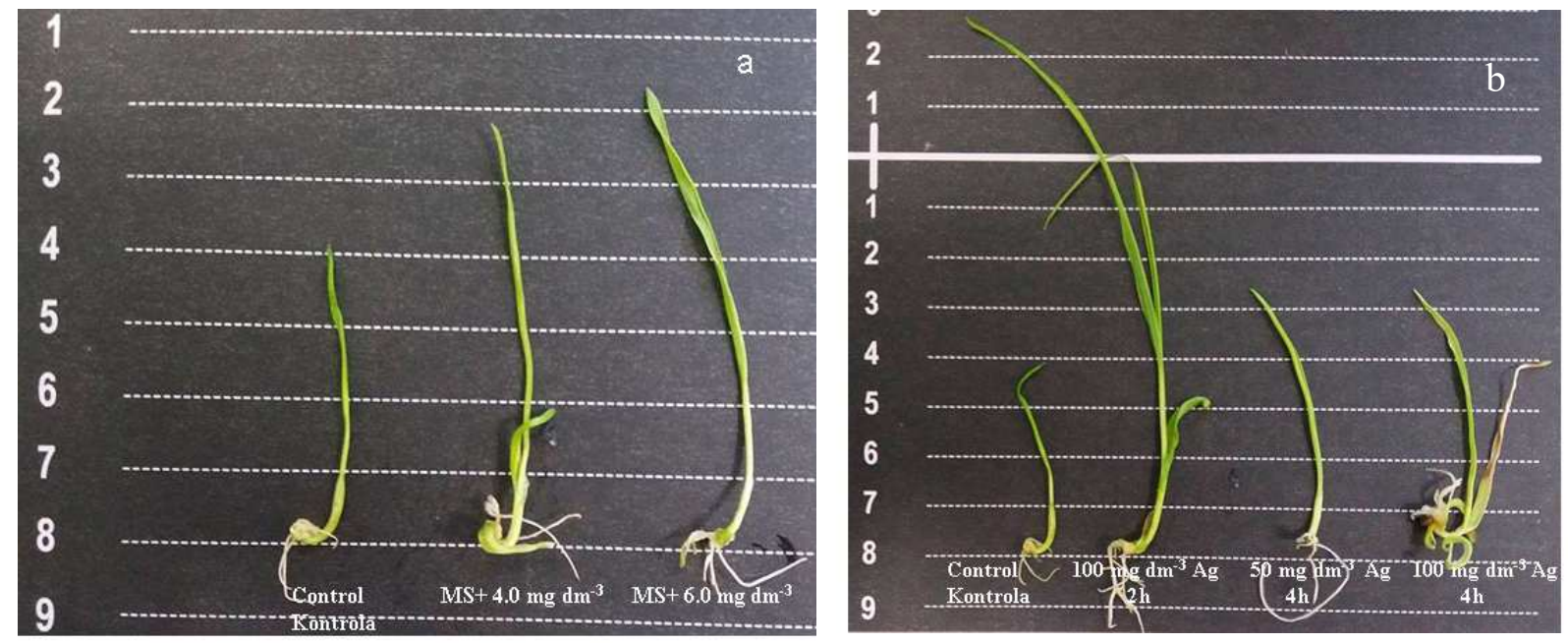

Fig. 1. Barley seedlings obtained on control MS medium, MS medium with addition of 4.0 i $6.0 \mathrm{mg} \cdot \mathrm{dm}^{-3}$ nano-silver (a) and after embryos immersion in 50 and $100 \mathrm{mg} \cdot \mathrm{dm}^{-3}$ of nano-silver solution for 2 and 4 hours (b)

Ryc. 1. Siewki jęczmienia jarego ‘Eunova' z pożywki kontrolnej MS, MS uzupełnionej 4,0 i 6,0 mg · $\mathrm{dm}^{-3}$ nanosrebra (a) oraz po moczeniu w 50 i $100 \mathrm{mg} \cdot \mathrm{dm}^{-3}$ roztworze nanosrebra w czasie 2 i $4 \mathrm{~h}$ (b)

Hue describes the visible colour. Index of $L^{*}$ is usually useful for tracking colour changes. The $a^{*}$ value, providing information of the position in the colour gamut between green and red, measured on the leaf surface. The leaf surface colour defined by the $b^{*}$ parameter, indicating the location on the axis between yellow and blue colours. In present study barley seedlings obtained from embryos submerging in $50 \mathrm{mg} \cdot \mathrm{dm}^{-3}$ for $4 \mathrm{~h}$ and $100 \mathrm{mg} \cdot \mathrm{dm}^{-3}$ for $2 \mathrm{~h}$ of nano-silver had higher indicators of $a^{*}$ parameters (by 28.5\%) than the control. In contrast, higher concentration of nano-silver particles in MS medium $\left(6.0 \mathrm{mg} \cdot \mathrm{dm}^{-3}\right.$ ) and longer time (4 hours) of embryos submerging in higher concentration of nano-silver solution $\left(100 \mathrm{mg} \cdot \mathrm{dm}^{-3}\right)$ increased the intensity of yellow colour (parameter $b^{*}$ ) of seedlings by $62 \%$ and $44 \%$, respectively, in comparison to the control (Fig. 2). Obtained results are in agreement with 
Pacewicz and Gregorczyk (2009) and Ochmian et al. (2013). They showed that the chlorophylls $\left(\mathrm{Chl} a\right.$ and $\mathrm{Chl} b$ ) content is highly correlated with the-green colour index - parameter $\mathrm{a}^{*}$, which is responsible for the green colour.

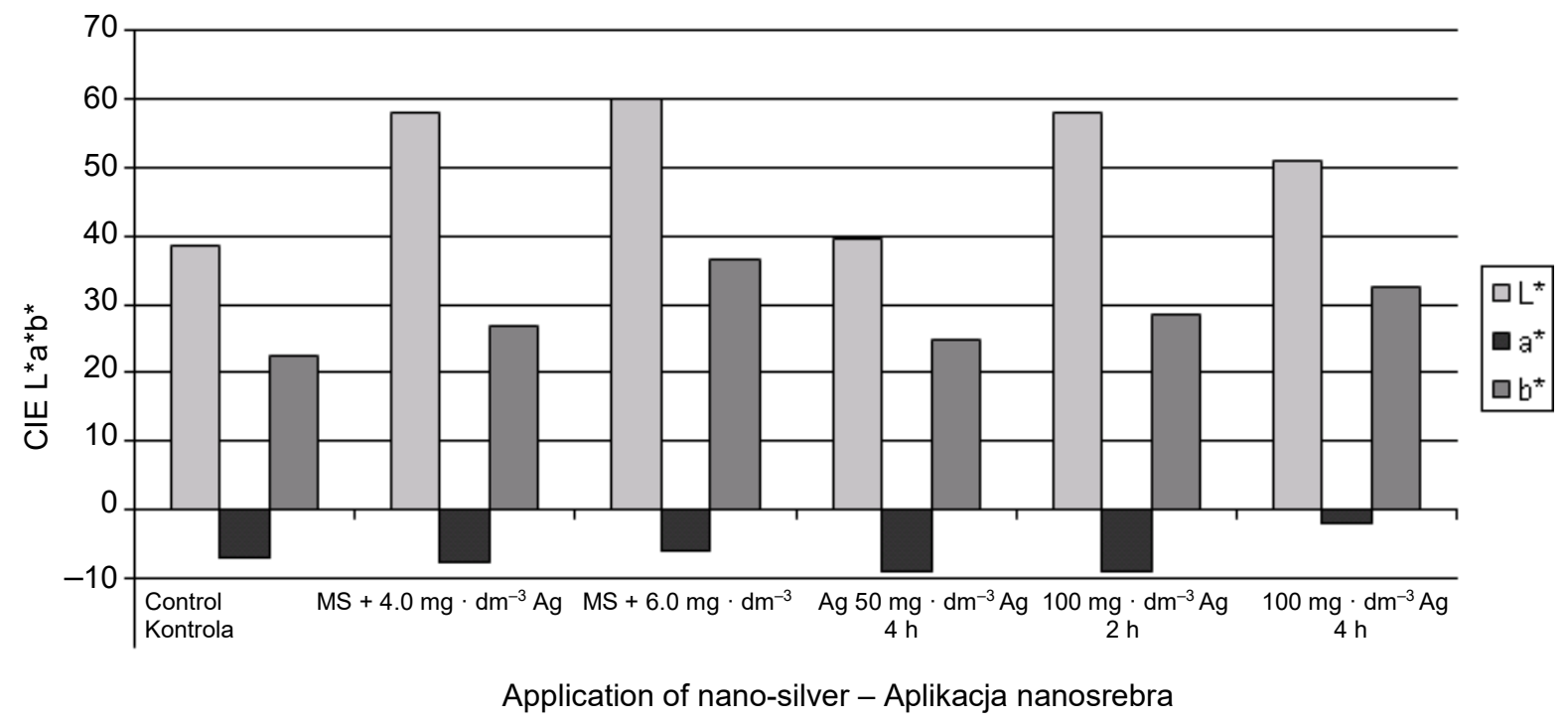

Fig. 2. Effects of nano-silver applications on leaves colour space using $C I E L^{*} a^{*} b^{*}$ system $\left(L^{*}-\right.$ the lightness coefficient, $a^{*}$ - green colour and $b^{*}$ - yellow colour) in spring barley 'Eunova' Ryc. 2. Wpływ aplikacji nanosrebra na barwę liści siewek jęczmienia jarego 'Eunova' metodą CIE L*a*b* ( ${ }^{*}$ - współczynnik jasności, $a^{*}-$ kolor zielony, $b^{*}-$ kolor żółty $)$

According to Ochmian et al. $(2013,2014)$ the amount of chlorophyll in leaves is connected with more nutrients in the medium. In the present study medium composition in each combination of the experiment was on the same level of macro- and microelements. Hence, differences in the colour of barley seedlings may, therefore, result from the presence of nano-silver particles in the plant.

\section{CONCLUSIONS}

1. The highest disinfection efficiency $(80 \%)$ was obtained after submerging of barley embryos in $100 \mathrm{mg} \cdot \mathrm{dm}^{-3}$ nano-silver for 2 hours.

2. Addition to MS medium of nano-silver or submerging of barley embryos in $100 \mathrm{mg} \cdot \mathrm{dm}^{-3}$ for 2 hours increased seedlings height and roots length compared with control.

3. Nano-silver particles independent of its application reduced the barley leaf colour.

\section{REFERENCES}

Abdi G., Salehi H., Khosh-Khui M. 2008. Nano silver: a novel nanomaterial for removal of bacterial contaminants in valerian (Valeriana officinalis L.) tissue culture. Acta Physiol. Plant. 30, 709-714.

Amiri S., Ashtari S., Babaiy A.H., Nazari S.A., Khodadadi E., Khodadadi E., Sabzi M. 2013. Control of contamination during micropropagation process of Rootstocks Mariana (Prunus mariana). Ann. Biol. Res. 4(3), 149-151. 
Hunterlab. 2012. Measuring colour using hunter L, a, b versus CIE $1976 L^{*} a^{*} b^{*}$. 2012, AN 1005.00, from htpp://www.hunterlab.com/an-1005b.pdf, access: April 1-4, 2012.

Krupa-Małkiewicz M., Ochmian I. 2014. Propagation of blue honeysuckle (Lonicera caerulea L.) in in vitro culture. J. Basic App. Sci. 10,164-169.

Microbial contamination of plant tissue culture. Recent advances in plant tissue culture IV. 1996. Ed. E Herman. Shrub Oak, NY, Agritech. Cons., Inc., 84.

Murashige T., Skog F. 1962. A revised medium, for rapid growth and bioassays with tobacco tissue cultures. Physiol. Plant. 15(3), 473-479.

Nomiya K., Yoshizawa A., Tsukagoshi K., Kasuga N.C., Hirakawa S., Watanabe J. 2004. Synthesis and structural characterization of silver (I), aluminium (III) and cobalt (II) complexes with 4-isopropyltropolone (hinokitiol) showing noteworthy biological activities. Action of silver (I)-oxygen bonding complexes on the antimicrobial activities. J. Inorg. Bioch. 98, 46-60.

Ochmian I., Kubus M., Dobrowolska A. 2013. Description of plants and assessment of chemical properties of three species from the Amelanchier genus. Dendrobiology 70, 59-64.

Ochmian I., Dobrowolska A., Chelpinski P. 2014. Physical parameters and chemical composition of fourteen blackcurrant cultivars. Not. Bot. Hort. Agrobot. 42(1), 160-167.

Osman N.I., Awal A., Sidik N.J., Abdullah S. 2013. Callus induction and somatic embryogenesis from leaf and nodal explants of Lycium barbarum L. (Goji). Biotechnology 12(1), 36-45.

Pacewicz K., Gregorczyk A. 2009. Porównanie ocen zawartości chlorofilu chlorofilometrami SPAD-502 i N-Tester [Comparison values of chlorophyll kontent by chlorophyll meter Spad-502 and N-tester]. Folia Pomer. Univ. Technol. Stetin., Agric., Aliment., Pisc., Zootech. 269, 49-46. [in Polish]

Rostami A.A., Shahsavar A. 2009. Nano-Silver particles eliminate the in vitro contaminations of olive 'Mission' explants. Asian J. Plant. Sci. 8, 505-509.

Sarmast M., Salehi H., Khosh-Khui M. 2011. Nano-silver treatment is effective in reducing bacterial contaminations of Araucaria excelsa R. Br. var. glauca explants. Acta Biol. Hung. 62, 477-484.

Shokri S., Babaei A., Ahmadian M., Hessami S., Arab M.M. 2014. The effects of different concentrations of nano-silver on elimination of bacterial contaminations and phenolic exudation of Rose (Rosa hybrida L.) in vitro culture. Intl. J. Farm. Alli Sci. 3(1), 50-54.

Sondi I., Salopek-Sondi B. 2004. Silver nanoparticles as antimicrobial agent: a case on E. coli as a model for Gram-negative bacteria. J. Coll. Interf. Sci. 275, 177-182.

Tarinejad A. 2013. Effects of disinfectants and antibiotics on contamination during propagation of walnut (Juglans regia L.). Res. Crops. 14(1), 219-225.

Teixeira S.L., Ribeiro J.M., Teixeira M.T. 2006. Influence of $\mathrm{NaClO}$ on nutrient medium sterilization and on pineapple (Ananas comosus cv Smooth cayenne) behavior. Plant Cell. Tiss. Organ Cult. 86, 375-378.

Teixeira da Silva J.A., Winarto B., Dobránszki J., Cardoso J.C., Zeng S. 2016. Tissue disinfection for preparation of Dendrobium in vitro culture. Folia Hort. 28(1), 57-75.

Tiwari A.K., Tripathi S., Lal M., Mishra S. 2012. Screening of some chemical disinfectants for media sterilization during in vitro micropropagation of sugarcane. Sugar Tech. 14(4), 364-369.

Wrolstad R.E., Durst R.W., Lee L. 2005. Tracking color and pigment changes in anthocyanin products. Trends Food Sci. Technol. 16, 423-8.

Zeng Y. 2014. Optimization of the method to obtain effective sterile explants in tissue culture of Ardisia mamillata Hence. Agricult. Sci. Tech. 15(6), 917-936.

Abstract. One of the available methods to control in vitro contaminations is nano-silver. Nanosilver is a non-toxic material which shows high capabilities in eliminating microorganisms, e.g., bacteria, viruses or fungus. The aim of the current study was to evaluate the potential of nano-silver particles on decontamination, growth parameters (plant length, root length) and leaves colour of spring barley 'Eunova' in in vitro culture. Plant material consisted of embryos of barley which were placed on MS medium supplemented with 4.0 and $6.00 \mathrm{mg} \cdot \mathrm{dm}^{-3}$ of nano-silver or 
submerged in 50 or $1000 \mathrm{mg} \cdot \mathrm{dm}^{-3}$ of nano-silver for 2 or $4 \mathrm{~h}$. The control consisted of embryos treated with $70 \%$ alcohol. After 28 days it was observed, that both of the disinfection methods, operating time as well as concentrations of nano-silver, had an influence on a number of contaminations, shoot and root length and colour of the barley leaves. The smallest efficiency $\left(100 \%\right.$ contaminations) was found after embryos submerged in $50 \mathrm{mg} \mathrm{dm}^{-3}$ of nano-silver for $2 \mathrm{~h}$. On the other hand, the best disinfection efficiency ( $0 \%$ infection) was obtained when $4.00 \mathrm{mg} \cdot \mathrm{dm}^{-3}$ nano-silver was added to MS medium. Barley embryos soaked in $100 \mathrm{mg} \cdot \mathrm{dm}^{-3}$ in nano-silver solution and grown on MS media with addition of nano-silver independent of their concentration showed similar disinfection effectiveness. 